\title{
GERAKAN KEWARGANEGARAAN EKOLOGIS SEBAGAI UPAYA PEMBENTUKAN KARAKTER PEDULI LINGKUNGAN
}

\author{
ECOLOGICAL CITIZENSHIP MOVEMENT AS AN EFFORTS \\ FOR ENVIRONMENTAL CARE CHARACTERS BUILDING
}

\author{
Setiawan Gusmadi, Samsuri \\ Program Magister Pendidikan Pancasila dan Kewarganegaraan \\ Universitas Negeri Yogyakarta \\ Jalan Colombo 1, Yogyakarta \\ email: gusmadi.setiawan@gmail.com
}

\begin{abstract}
: this article aims to discuss the forms of activities of the ecological citizenship movement and the formation of environmentally care characters. The study uses a qualitative approach with a case study. Data collection uses observation, interviews, and documentation studies. The ecological citizenship movement is carried out through the post-mining reclamation movement, mangrove planting movement, resistance movement, and waste care action movement. Efforts to build the character of environmental care are instilled through environmental education in the community and students in schools, clear law enforcement for mining companies, and campaigns through social media about environmental conditions.
\end{abstract}

Keywords: Community-Based Education, Ecological Citizenship Movement, Environmental Care Character

\begin{abstract}
Abstrak: artikel ini bertujuan untuk membahas bentuk kegiatan gerakan kewarganegaraan ekologis dan pembentukan karakter peduli lingkungan. Kajian menggunakan pendekatan kualitatif dengan jenis studi kasus. Pengumpulan data menggunakan observasi, wawancara, dan studi dokumentasi. Gerakan kewarganegaraan ekologis dilakukan melalui gerakan reklamasi pasca penambangan, gerakan penanaman bakau (mangrove), gerakan perlawanan, gerakan aksi peduli sampah. Upaya pembentukan karakter peduli lingkungan ditanamkan melalui pendidikan lingkungan pada masyarakat dan siswa di sekolah, penegakan hukum yang jelas untuk perusahaan pertambangan, dan kampanye melalui media sosial mengenai kondisi lingkungan.
\end{abstract}

Kata Kunci: Pendidikan Berbasis Masyarakat, Gerakan Kewarganegaraan Ekologis, Karakter Peduli Lingkungan

\section{PENDAHULUAN}

Sistem perlindungan lingkungan membantu memastikan kesejahteraan generasi masa depan yang bergantung pada sumber daya alam untuk mata pencaharian. Beberapa fenomena kasus perilaku yang mencemari dan/atau merusak lingkungan ialah pencemaran udara, pembalakan hutan, pembuangan sampah tidak pada tempatnya, dan pertambangan yang merusak keanekaragaman hayati di darat, sungai, dan laut. Uraian tersebut jelas menunjukkan bahwa kelestarian dan kerusakan lingkungan sangat ditentukan semua lapisan pemangku kepentingan (stakeholder) seperti, pemerintah, masyarakat setempat, NGO, penambangan dan penegakan hukum. Indonesia sebagai negara yang kaya akan sumber daya memiliki masyarakat sipil yang relatif kuat dalam tata kelola lingkungan walaupun pemerintah masih aktor yang paling kuat (Shin, 2015), sehingga agar peran masyarakat semakin 
kuat maka diperlukan pendidikan lingkungan berbasis masyarakat.

Pendidikan lingkungan berbasis masyarakat dapat berfungsi sebagai pemikiran yang mengintegrasikan pembangunan ekonomi berkelanjutan. Program Pendidikan Ekologi dan Sumber Daya Alam (Ecology and Natural Resource Education) yang dilaksanakan oleh LSM memiliki potensi untuk berkontribusi pada pendidikan berkualitas dan kewarganegaraan demokratis. Upaya masyarakat dan LSM tidak mencukupi sehingga diperlukan keterlibatan pemerintah untuk menempatkannya sebagai agenda universal untuk pendidikan kewarganegaraan (Ghosh, 2015). Sistem pendidikan yang dilakukan LSM diharapkan memberikan pelayanan sosial secara teroganisisir kepada kelompok masyarakat yang membutuhkan secara langsung. Kajian institut dialog di Mesir dari laporan "Citizens in the Making" program pendidikan kewarganegaraan yang dilakukan oleh LSM berfokus pada kaum muda. Program tersebut meliputi sektor publik dan organisasi masyarakat sipil untuk penyebaran nilai pendidikan kewarganegaraan seperti media, partai politik, sektor swasta, dan lembaga keagamaan (Danish Egyptian Dialogue Institute, 2016).

Upaya pembentukan karakter peduli lingkungan mempunyai sistem yang dibangun sesuai dengan pengembangan gerakan kewarganegaraan ekologis yang baik. Penelitian Prasetiyo \& Budimansyah (2016) menyatakan bahwa pemberian pengetahuan dan keterampilan menjadikan masyarakat cerdas, kritis dalam menerapkan pendidikan karakter peduli lingkungan. Pembudayaan karakter peduli lingkungan dilakukan melalui kegiatan seperti pembentukan bank sampah, kegiatan pembuangan sampah pada tempatnya, penanaman tanaman produktif, kerja bakti, mengelola sampah organik, pembuatan kerajinan dari daur ulang sampah, dan melakukan reboisasi (Triwardani \& Sarmini, 2013). Karakter peduli lingkungan sangat diperlukan dalam pendidikan nonformal melalui pemerintah daerah dan organisasi berbasis lingkungan yang ada di Bangka Belitung

Provinsi Kepulauan Bangka Belitung sebelumnya merupakan bagian dari Provinsi Sumatera Selatan yang dibentuk berdasarkan Undang-Undang Nomor 27 Tahun 2000 yang memiliki potensi di bidang perkebunan, perikanan, pertambangan, dan pariwisata serta mempunyai prospek yang baik bagi pemenuhan kebutuhan pasar dalam negeri maupun luar negeri. Sebagai penghasil lada putih dan timah terbesar di Indonesia, pemerintah harus melakukan pengawasan yang serius terhadap lahan produktif pertanian lada putih agar tidak menjadi lahan pertambangan dan perkebunan kelapa sawit yang berskala besar. Hal ini diperkuat oleh Zamroni (2007) yang menyatakan bahwa perkembangan masyarakat modern diawali dari ekonomi berbasis produksi pertanian dan pertambangan dengan tenaga manusia atau tenaga mesin yang membentuk masyarakat yang agraris. Akan tetapi, keberadaan perusahaan pertambangan timah dan hutan tanaman industri menyebabkan perlawanan masyarakat setempat yang mengindikasikan tejadinya ketidakadilan bagi petani lada dan nelayan akibat kekuasaan ekonomi kapitalis perusahaan.

Isu strategis Rencana Pembangunan Jangka Menengah Daerah (RPJMD) Pemerintah Provinsi Kepulauan Bangka Belitung tahun 2017-2022 saat ini diidentifikasi berdasarkan faktor yang memengaruhi keberhasilan dan kegagalan kinerja pada masa lalu. Permasalahan mendasar dalam pengelolaan lingkungan hidup oleh Dinas Lingkungan Hidup (DLH) adalah: (a) pengelolaan sumber daya tambang yang masih mengabaikan kelestarian lingkungan yang mengakibatkan penurunan daya dukung lingkungan dan penurunan kualitas dan kuantitas sumber daya alam, (b) kurang berfungsinya aparatur penegak hukum dalam menindak penjahat lingkungan yang mengakibatkan semakin maraknya kegiatan 
perusakan lingkungan hidup, (c) rendahnya tingkat kesadaran dan peran serta masyarakat dalam menjaga kelestarian lingkungan hidup, (d) banjir, (e) degradasi lingkungan sungai dan pantai akibat pertambangan, dan (f) belum optimalnya pengelolaan lahan kritis kritis reklamasi pasca penambangan (DLH, 2017).

Penanaman kesadaran terhadap masyarakat mengenai isu lingkungan hidup memerlukan biaya yang cukup besar. Kajian Latchem (2018) menyatakan bahwa pengurangan biaya melalui fasilitas produksi media dapat menggunakan radio, televisi, dan internet untuk tujuan meningkatkan kesadaran publik dan pemahaman tentang masalah lingkungan, mendokumentasikan keadaan degradasi lingkungan, melobi untuk reformasi kebijakan, dan mengumpulkan dana untuk kampanye. Masalah pencemaran air maupun tanah merupakan bagian yang tidak dapat dihindarkan dari kegiatan pembangunan. Lingkungan yang tercemar akibat kegiatan penambangan masyarakat Bangka Belitung akan berdampak negatif pada kesehatan, perubahan iklim, keindahan alam, serta keseimbangan ekosistem dan sumber daya alam. Keberhasilan terlaksananya pembangunan tentunya mempunyai permasalahan pengolahan lingkungan hidup yang ada lima di Indonesia yaitu, kebijaksanaan, peraturan perundangundangan, kelembagaan, dukungan data dan informasi lingkungan serta teknologi pengelohan lingkungan, dan peran serta masyarakat (Murdiantum \& Daryanto, 2015).

Sikap dan perilaku manusia telah melahirkan kebijakan dan pola hidup yang menghancurkan lingkungan hidup termasuk kehidupan manusia (Keraf, 2014). Oleh karena itu, diperlukan gerakan lingkungan yang berupaya melakukan penyadaran atas saling ketergantungan manusia dan alam yang dapat memengaruhi pola hidup dan perilaku manusia (Kalidjernih, 2011). Perluasan gerakan lingkungan memberikan gambaran pesat topik isu kampanye lingkungan.
Upaya penyadaran kritis yang dibawa oleh Gabungan Pecinta Alam Belitung (GAPABEL) cukup beragam tentang kepedulian terhadap lingkungan yaitu penolakan tambang laut, perambahan hutan bakau dan juga kesadaran tentang kepedulian terhadap sampah. Sampah sebagai masalah lingkungan menjadi tugas pemerintah untuk mencari solusi dan pandangan untuk meminimalisir dampak lingkungan dari sampah. Pemisahan sampah, daur ulang, pengomposan, biometanisasi, dan biogas adalah beberapa solusi untuk mengubah perilaku masyarakat (Anantharaman, 2014).

Isu kerusakan lingkungan di Bangka Belitung sudah lama dirasakan oleh masyarakat lokal. Kini ada beberapa komunitas berbasis lingkungan yang muncul untuk mengawasi kebijakan penting pemerintah. Beberapa kasus yang berkaitan tentang lingkungan hidup menunjukkan bahwa masyarakat harus mempunyai pengetahuan untuk mengelola, menjaga, dan melestarikan lingkungan yang dikenal dengan istilah kewarganegaraan ekologis (ecological citizenship). Gerakan kewarganegaraan ekologis diharapkan menimbulkan kesadaran lingkungan global serta munculnya opini publik yang semakin peduli terhadap pelestarian lingkungan lokal dan global yang menambahkan makna baru pada konsep citizenship. Generasi baru ekologi sebagai kewarganegaraan ekologis adalah bagian dari generasi baru jenis citizenship yang menganggap serius politik kewajiban (Smith \& Pangsapa, 2008). Program bersih-bersih pantai, pembibitan mangrove, penanaman pohon mangrove diwujudkan dengan kesadaran bersama untuk mewujudkan kewarganegaraan ekologis (Nurmayanti \& Harmanto, 2017).

Munculnya isu lingkungan membawa lahirnya gerakan organisasi berbasis lingkungan. Proses mengembalikan hak-hak rakyat untuk berpartisipai dalam kegiatan LSM lingkungan terbesar di Indonesia dikenal WALHI (Wahana Lingkungan Hidup Indonesia) yang berkembang di Bangka 
Belitung pada tahun 2008. WALHI populer dengan kegiatannya dalam mengangkat masalah lingkungan untuk Indonesia terutama pada wilayah seperti Provinsi Kepulauan Bangka Belitung yang banyak terdapat isu kerusakan lingkungan akibat dari penambangan. Laporan UNDP tentang Provincial Climate Public Expenditure and Institutional Review (CPEIR) Bangka Belitung Island of Indonesia menyatakan bahwa WALHI (Wahana Lingkungan Hidup) merupakan LSM yang sering mengangkat isu kerusakan lingkungan (UNDP, 2015). Demokrasi merupakan faktor utama yang berkontribusi terhadap tindakan politik yang dilakukan oleh WALHI (Nomura, 2009).

Peran dari organisasi-organisasi masyarakat Bangka Belitung memberi kontribusi dalam sebuah perubahan mengembalikan kerusakan lingkungan pasca penambangan. Berdirinya berbagai organisasi masyarakat memperkuat partisipasi kepedulian terhadap lingkungan. Partisipasi sukarela dengan membentuk asosiasi-asosiasi masyarakat kewargaan dapat melakukan kebaikan bersama sebagai perwujudan partisipasi aktif di ruang publik (Samsuri, 2011). Sasaran pendidikan nonformal menuntut pendanaan yang lebih baik dan lebih berkelanjutan dan kolaborasi yang lebih erat antara pemerintah, lembaga pendidikan, LSM, sektor swasta, dan masyarakat itu sendiri (Latchem, 2018). Pendidikan terkait isu ekologi mengintegrasikan pembangunan nasional yang memfokuskan upaya penyadaran masyarakat yang bertanggung jawab terkait kerusakan lingkungan hidup.

Pembudayaan sebagai proses penanaman karakter melalui berbagai kegiatan yang melibatkan masyarakat. Manusia berkarakter memiliki kepedulian terhadap lingkungan fisik dan lingkungan sosial. Kualitas kesadaran manusia tidak terpisahkan dari lingkungan yang mempunyai tingkat kualitas keseimbangan lingkungan hidup. Karakter peduli lingkungan merupakan sikap selalu berupaya untuk mencegah kerusakan alam di sekitarnya dan mengembangkan upaya-upaya untuk memperbaiki kerusakan alam yang sudah terjadi (Gunanti, 2012). Kajian ini diharapkan mampu menyajikan informasi yang berkaitan dengan nilainilai karakter peduli lingkungan berupa sikap dan tindakan yang selalu berupaya mencegah kerusakan pada lingkungan alam sekitarnya dan upaya memperbaiki kerusakan alam yang sudah terjadi.

\section{METODE}

Penelitian ini menggunakan pendekatan kualitatif. Jenis penelitian ini adalah studi kasus yang menyelidiki secara cermat sebuah program, peristiwa, aktivitas, proses, atau sekelompok individu (Creswell, 2015). Pembahasan menitikberatkan pada gerakan kewarganegaraan ekologis (ecological citizenship) sebagai upaya pembentukan karakter peduli lingkungan di Bangka Belitung.

Penentuan subjek penelitian menggunakan teknik purposive yang terdiri atas WALHI, GAPABEL dan DLH Provinsi Kepulauan Bangka Belitung. Teknik purposif merupakan suatu teknik penelitian memilih dan memutuskan individuindividu dan tempat untuk diteliti karena mereka dapat secara spesifik memberikan pemahaman tentang masalah dan fenomena yang berkaitan dengan penelitian (Creswell, 2015). Pengumpulan data dilakukan melalui wawancara, observasi, dan dokumentasi. Data penelitian dianalisis dengan teknik analisis kualitatif model interaktif. Kegiatan yang dilakukan dalam analisis data yaitu reduksi data, klasifikasi data, penyajian data, dan penarikan kesimpulan.

\section{HASIL DAN PEMBAHASAN}

\section{Gerakan Kewarganegaraan Ekologis}

Gerakan-gerakan lingkungan membawa implikasi penting kepada konsepsi kewarganegaraan (Kalidjernih, 2011). Gerakan lingkungan dibagi menjadi tiga 
komponen (Aditjondro, 2003), yaitu: (a) gerakan lingkungan yang terorganisir atau gerakan lingkungan yang sukarela, contohnya WALHI di Indonesia, (b) gerakan lingkungan publik yang merupakan bentuk gerakan berbasis masyarakat, tindakan sehari-hari yang menyatakan keengganan atau kesukaan terhadap ekosistem, (c) gerakan lingkungan yang berbasis pemerintah atau lembaga-lembaga yang dibentuk oleh pemerintah mengenai upaya penanganan masalah lingkungan hidup seperti Dinas Lingkungan Hidup di Indonesia. Dari komponen-komponen tersebut gerakan lingkungan mempunyai konsistensi dalam menangani isu-isu permasalahan lingkungan yang ada di Bangka Belitung.

Salah satu penerapan pendidikan kewarganegaraan dalam penyelamatan lingkungan hidup dikenal dengan istilah kewarganegaraan ekologis (ecological citizenship). Definisi kewarganegaraan ekologis dari Kennedy (2011) adalah memasukkan dimensi budaya informasi yang berbasis lingkungan. Jagers, et al. (2014) menafsirkannya dengan keadilan sosial, menantang perbedaan publik-swasta dan tanggung jawab. Humphreys (2009) mendefinisikan sebagai kegiatan yang berusaha untuk memiliki suara keadilan bagi masyarakat miskin pedesaan, masyarakat adat dan kelompok-kelompok terpinggirkan lainnya. Anantharaman (2014) menyoroti keterlibatan sukarela oleh individu-individu melalui mata pencaharian dalam menghasilkan sistem perilaku peduli lingkungan, sedangkan Smith \& Pangsapa (2008) melihat pada aspek politik kewajiban pada ikatan antar aktor seperti organisasi sipil, pemerintah, dan badan antar pemerintah. Pencegahan masalah-masalah lingkungan dengan membentuk kewarganegaraan ekologis dapat dilakukan melalui LSM dan komunitas lainnya yang kompromi dan adil untuk mencapai keseimbangan pengelolaan sumber daya alam (Keulartz, 2018).
Dalam bidang tata kelola lingkungan terdapat hubungan antara lembaga organisasi berbasis lingkungan, berbagai stakeholder termasuk negara, perusahaan, organisasi internasional, dan LSM yang bekerja sama melalui perjanjian, inisiatif, dan program untuk mengatasi masalah lingkungan (Latta \& Wittman, 2014). Menurut Murdiantum \& Daryanto (2015) pengendalian pencemaran dan kerusakan lingkungan diperlukan kerja sama antara pemerintah, LSM, dan universitas. Gerakan lingkungan yang terorganisasi dibentuk dengan tujuan untuk menentang kekuasaan dan keadaan krisis lingkungan.

Gerakan kewarganegaraan ekologis dalam penelitian ini sebagai gerakan lingkungan yang dilakukan pemerintah khususnya DLH dan organisasi berbasis lingkungan seperti WALHI dan GAPABEL yang bekerjasama untuk mewujudkan lingkungan yang bersih, sehat, dan bebas dari pencemaran. Beberapa temuan gerakan kewarganegaraan ekologis di Provinsi Kepulauan Bangka Belitung yaitu, gerakan reklamasi pasca penambangan, gerakan penanaman bakau, gerakan perlawanan, dan gerakan aksi peduli sampah.

\section{Gerakan Reklamasi Pasca Penambangan}

Reklamasi yang tepat dari lahan pasca penambangan telah dirancang sebagai solusi untuk mempermudah pembebasan lahan dengan mengusulkan suatu sistem pengembalian tanah sesuai dengan tanggung jawab sosial perusahaan industri. Faktor utama yang memengaruhi reklamasi ialah penanaman kembali hutan pada skala waktu yang sebanding (Singh, et al, 2017). Peraturan Daerah Provinsi Kepulauan Bangka Belitung Nomor 7 Tahun 2014 tentang Pengelolaan Pertambangan Mineral menyatakan bahwa reklamasi merupakan kegiatan yang dilakukan sepanjang tahapan usaha pertambangan untuk menata, memulihkan, dan memperbaiki kualitas lingkungan dan ekosistem agar dapat berfungsi kembali sesuai peruntukannya. 
Gerakan reklamasi pasca penambangan terhadap bekas lahan yang telah diambil kekayaan alamnya merupakan kewajiban perusahaan. PT TIMAH Tbk mempunyai program reklamasi selama lima tahun 20152019. Luas reklamasi pasca penambangan yang dilakukan PT TIMAH Tbk pada tahun 2017 sebagai realisasi reklamasi tanggung jawab perusahaan (CSR) terhadap lingkungan sebanyak 688,71 hektar dari 2.027 hektar yang ditargetkan (Laporan Tahunan PT Timah Tbk, 2017). Reklamasi lahan yang rusak menjadi proses yang lambat atau relatif cepat tergantung pada tingkat kerusakan. Oleh karena itu, skema reklamasi mempertimbangkan beberapa jenis intervensi manusia dapat dipercepat untuk proses mengembalikan lingkungan yang rusak (Antwi, et al, 2014).

Gerakan yang dilakukan WALHI dan GAPABEL mengusulkan bahwa pengelolaan hutan berbasis masyarakat dengan pengakuan yang tepat atas hak atas tanah. Hak atas tanah tersebut adalah satu-satunya cara untuk mencegah deforestasi dan mempromosikan konservasi hutan jangka panjang yang efektif (Toumbourou, 2011). Kegiatan pengembalian lahan hutan yang rusak agar menjadi produktif kembali merupakan pembentukan untuk mengembangkan kewarganegaraan ekologis. Oleh karena itu, diperlukan kerjasama stakeholder untuk mendorong perilaku cinta lingkungan dengan memanfaatkan lahan produktif menjadi perkebunan lada putih dan tidak melakukan penambangan yang dilakukan perusahaan maupun tambang inkonvensional (TI). Keterlibatan masyarakat yang bertujuan mendukung kelestarian lingkungan adalah untuk bertahan hidup dengan melestariakan kearifan lokal petani lada putih yang dikenal pada pasar dunia.

\section{Gerakan Penanaman Bakau}

Gerakan penanaman bakau dilakukan terlebih dahulu dengan mengadakan pembibitan. Kegiatan pembibitan dilaksanakan oleh dinas lingkungan hidup. Program kegiatan pembibitan ini melibatkan kader-kader muda secara langsung memberikan contoh proses pembibitan sampai layak tanam. Pelaksanaan kegiatan penanaman bakau selalu rutin dilakukan dengan melibatkan masyarakat, komunitas-komunitas lingkungan, perusahaan-perusahaan maupun sekolahsekolah yang berada di sekitar pesisir pantai. Penanaman pohon bersama yang dilakukan sebagai bagian dari program berkontribusi pada pelestarian hutan sehingga membantu mengurangi efek samping dari perubahan iklim (Bozek, 2011).

Kegiatan praktik langsung dan sosialisasi pembibitan dan penanaman bakau dilakukan di daerah yang kondisi lahannya sudah kritis. Upaya dalam memberikan pengetahuan dan keterampilan kepada kader-kader muda melalui kerja nyata bertujuan agar dapat mewujudkan partisipasi kader-kader muda dalam upaya pembentukan karakter peduli lingkungan. Hasil penelitian Nurmayanti \& Harmanto (2017) mengemukakan bahwa strategi ecological citizenship salah satunya melalui yayasan mangrove center melalui program konservasi, pembibitan oleh sekolah peduli lingkungan yang bertujuan untuk membangun terjalinnya hubungan baik manusia dengan alam sehingga masyarakat memiliki kesadaran terhadap hak dan kewajibannya dalam menjaga kelestarian lingkungan. Dalam hal ini, pembentukan karakter peduli lingkungan di Bangka Belitung dilakukan oleh pemerintah setempat bekerja sama dengan sekolah-sekolah, organisasi berbasis lingkungan, dan masyarakat untuk ikut berpartisipasi dalam kegiatan bersihbersih pantai untuk menjaga keindahan pantai dan penanaman mangrove.

Program perlindungan lingkungan bergantung pada aktivitas masyarakat lokal terutama di kalangan anak-anak dan remaja bertujuan untuk dampak sosial yang luas dimulai dengan komunitas lokal, struktur pemerintah, organisasi sosial dan entitas bisnis. Program hari pohon (tree 
day) mengintegrasikan masyarakat pada berbagai level antara lain perlindungan lingkungan (environmental protection); kehidupan ekonomi dan kehidupan sosial (Bozek, 2011). Konsep kewarganegaraan ekologis tidak akan muncul secara spontan, namun harus diciptakan dengan keterlibatan dalam kegiatan politik yang mendukung penanaman bakau. Oleh karena itu, warga negara berkewajiban untuk menjaga hutan dari kerusakan, ekosistem hewan, kelestarian gunung, dan berhati-hati untuk memulai setiap pembangunan yang mungkin memiliki dampak buruk pada ekosistem.

\section{Gerakan Perlawanan}

Aksi penolakan tambang laut dan perambahan hutan adalah bentuk pengawasan terhadap kebijakan-kebijakan strategis pemerintah daerah Provinsi Kepulauan Bangka Belitung dalam mengelola sember daya alam. Gerakan kritik LSM dan pers, demo dan desakan masyarakat agar perusahaan memperbaiki kinerjanya adalah hal positif dan seharusnya didukung oleh pemerintah (Keraf, 2010). Keberadan organisasi berbasis lingkungan memiliki kekuatan ideologi yang besar dalam membawa perubahan sosial baru.

Penyusunan program pembangunan lingkungan hidup yang baik memerlukan sinkronisasi antar lembaga dengan fungsinya masing-masing. Gerakan lingkungan dapat menekan berbagai organisasi untuk membeli tenaga hijau melalui petisi, tuntutan hukum, boikot, dan protes (Vasi, 2011). Ketergantungan masyarakat terhadap lingkungan membuat mereka menolak dengan pertambangan yang dilakukan oleh perusahaan timah dan hutan tanaman industri, sehingga perlawanan terus dilakukan hingga benar-benar dihentikan. Di sisi lain masyarakat lokal dan pemerintah menerima dampak negatif dari keberadaan tambang timah dengan kerusakan lingkungan (Irawan, et al, 2014).
Fenomena kasus penambangan di Provinsi kepulauan Bangka Belitung menimbulkan berbagai bentuk aksi penolakan untuk menjamin ketersediaan sumber daya alam. Dalam konteks ini, aliansi organisasi berbasis lingkungan yang melakukan aksi perlawanan ditandai dengan penentangan wilayah yang akan menjadi Izin Usaha Penambangan (IUP) dan Hutan Tanaman Industri (HTI). Penelitian Renthlei (2016) mengatakan bahwa pemerintah memanfaatkan layanan dari organisasi nonpemerintah (LSM) yang melibatkannya dalam kampanye kesadaran untuk perlindungan lingkungan di masyarakat. Aksi penolakan senantiasa akan berkembang ketika kehidupan manusia mengalami problematika yang erat hubungannya dengan kekerasan untuk menuntut perubahan melalui gerakan-gerakan protes tersebut. Proses perjuangan gerakan revolusi pasca industri pertambangan mendorong masyarakat Bangka Belitung untuk membentuk lembaga organisasi-organisasi yang berkaitan dengan lingkungan hidup.

\section{Gerakan Aksi Peduli Sampah}

Aksi simpatik organisasi berbasis lingkungan menunjukkan perannya dalam membersihkan sampah yang bertujuan untuk meningkatkan pengetahuan dan kesadaran masyarakat dalam meminalisir pembuangan sampah plastik di pantai wisata. Kampanye bersih-bersih sampah di pantai menunjukkan gerakan kewarganegaraan ekologis dalam membentuk karakter peduli lingkungan. Program pemerintah yang dilakukan Dinas Lingkungan Hidup (DLH) yaitu melakukan sosialisasi dilaksanakan di sekolah, kantor desa, puskesmas, pasar, dan perkantoran merupakan cara untuk memperkuat karakter peduli lingkungan.

Prinsip dasar ekologi akan berfungsi dengan baik apabila pembuangan limbah rumah tangga pada umumnya menggunakan tong sampah dan memanfaatkan daur ulang sampah (Anantharaman, 2014). Gerakan 
kewarganegaraan ekologis melalui aksi peduli sampah dengan melakukan bersihbersih pantai, pengadaan tong sampah oleh pemerintah desa di setiap pemukiman rumah warga, pengolahan sampah organik menjadi kompos, dan pengolahan sampah anorganik menjadi kerajinan tangan. Masyarakat tidak hanya paham mengenai isu-isu tata cara pengelolaan dan pelestarian lingkungan tetapi juga mampu terlibat langsung dalam pelestarian lingkungan sehingga secara sadar ikut berpartisipasi dan menjadi pembiasaan.

\section{Upaya Pembentukan Karakter Peduli Lingkungan}

Setiap warga Negara berkewajiban dan bertanggung jawab untuk menjaga lingkungan hidup yang baik dan sehat (Asshiddiqie, 2009). Partisipasi warga negara dalam mencegah pencemaran, kerusakan, dan melestarikan lingkungan hidup dapat dilakukan dengan kerja sama semua lapisan masyarakat. Upaya pembentukan karakter peduli lingkungan dilaksanakan melalui: pendidikan lingkungan, penegakan hukum yang jelas, dan kampanye media sosial.

\section{Pendidikan Lingkungan}

Pendidikan yang menekankan citizenship sebagai misi utama pendidikan lingkungan (environmental education) mengembangkan nilai-nilai lingkungan dan perilaku bertanggung jawab lingkungan. Pendekatan pendidikan lingkungan menyebabkan meningkatnya kesadaran dan pembelajaran tentang isu-isu lingkungan di kalangan siswa dan masyarakat. Penanaman kesadaran tersebut dapat dilaksanakan melalui jalur pendidikan, yaitu dengan adanya program penguatan pendidikan karakter di sekolah. Salah satu programnya adalah kebiasaan hidup bersih dan penghijauan sekolah yang membiasakan siswa untuk menjaga dan mencintai lingkungan (Awaliyah, Al Atok, \& Wulandari, 2018). Sosialisasi dalam mengembangkan pengetahuan diberikan kepada masyarakat dengan maksud untuk mengajak masyarakat memiliki kepedulian terhadap lingkungan.

Pendidikan lingkungan diharapkan dampaknya akan bertahan lama dan menumbuhkan kesadaran dan tindakan untuk berpartisipasi dalam masyarakat. Bentuk-bentuk partisipasi warga negara dalam pelestarian lingkungan hidup dilakukan melalui kegiatan-kegiatan masyarakat dan dunia pendidikan (Syahri, 2013). Pendidikan lingkungan merupakan proses mengenali konsep untuk mengembangkan keterampilan dan sikap yang diperlukan untuk memahami dan menghargai keterkaitan antar manusia, kebudayaannya, dan lingkungan. Pendekatan pendidikan lingkungan menyebabkan meningkatnya kesadaran dan pembelajaran tentang isu-isu lingkungan di kalangan siswa, mahasiswa, dan masyarakat. Berbagai kelembagaan pendidikan seyogyanya mengembangkan kebutuhan pengetahuan berdasarkan kondisi wilayah.

Pendidikan lingkungan memerlukan rumusan kebijakan dan implementasi yang menggabungkan dengan konsep kemampuan generasi mendatang yang harus fokus pada membantu individu dan kelompok untuk: (a) memiliki kesadaran dan kepekaan terhadap lingkungan dan masalah-masalah yang terkait dengannya, (b) mendapatkan pengalaman dan pemahaman dasar tentang lingkungan dan masalah yang terkait lingkungan, (c) memperoleh serangkaian nilai dan perasaan peduli terhadap lingkungan dan motivasi untuk berpartisipasi aktif dalam perbaikan dan perlindungan lingkungan, (d) memperoleh keterampilan untuk mengidentifikasi dan memecahkan masalah lingkungan, (e) dan terlibat aktif dalam upaya penyelesaian masalah lingkungan (Latchem, 2018). Upaya yang dilakukan oleh individu dan kelompok organisasi berbasis lingkungan di Bangka Belitung adalah menanamkan keberadaan lingkungan yang berkelanjutan 
ke dalam pendidikan nonformal dalam meningkatkan kesadaran masyarakat akan masalah lingkungan.

Pembinaan untuk memiliki kesadaran pengetahuan yang relevan tentang masalah lingkungan diperlukan kerja sama antara pemerintah dan organisasi berbasis lingkungan. Pada dasarnya DLH juga memberikan pengetahuan masyarakat melalui penilaian Kota Sehat atau Adipura Desa Kabupaten yang mewujudkan masyarakat yang sehat, lingkungan hidup yang lestari, serta menjadikan sampah sebagai sumber daya dalam nilai ekonomi. Program yang dilakukan WALHI dengan membentuk forum diskusi bersama mahasiswa, tokoh-tokoh desa, dan komunitas nelayan secara aktif menjadikan terbukanya pemahaman masyarakat untuk membangun kesadaran melestarikan sumber daya alam dan memperbaiki kerusakan lingkungan. Tujuan memberian pendidikan lingkungan yang dilakukan oleh GAPABEL melalui proses menyiapkan kader-kader yang peduli terhadap lingkungan dengan lebih banyak turun langsung ke masyarakat dan mempunyai rumah baca bertajuk Rumah Baca Akar GAPABEL. Pendidikan lingkungan berbasis masyarakat memperjuangkan keadilan mengenai kondisi lingkungan yang mengancam petani dan nelayan di Bangka Belitung. Oleh karena itu, pendidikan karakter peduli lingkungan disajikan dalam bentuk yang mudah dipahami dan diterima oleh masyarakat.

\section{Penegakan Hukum Lingkungan}

Hukum lingkungan internasional yang dinegosiasikan oleh negara-negara atas nama warganya menguraikan hak-hak dan kewajiban lingkungan (Humphreys, 2009). Menegakkan hukum lingkungan (environmental law) dengan benar sesuai kekuatan pengawasan sangat perlu untuk dilakukan. Lembaga swadaya masyarakat dan warga negara harus memainkan peran dalam implementasi undang-undang lingkungan. Undang-undang lingkungan hidup memberikan kesempatan kepada masyarakat untuk terlibat dalam pengeloaan lingkungan. Pemerintah dapat didorong untuk memainkan perannya yang lebih besar dalam penegakan hukum lingkungan.

Hukum lingkungan pada dasarnya adalah disiplin lintas sektor yang melibatkan undangundang negara yang terkait dengan pertanian, hukum pidana, manajemen bencana, energi, kehutanan, kesehatan, perumahan, penilaian dampak industri, hubungan internasional, mineral dan pertambangan, sumber daya alam, pengentasan kemiskinan, layanan publik, keamanan, perdagangan, air, satwa liar, dan sebagainya (UNEP \& CAEC, 2014). Aparatur penegak hukum harus secara tegas memberikan sanksi bagi pihak yang terbukti melakukan kejahatan merusak dan mencemari lingkungan hidup. Dari beberapa kasus-kasus masalah lingkungan hidup yang pernah terjadi, penegakan hukum lingkungan di Provinsi Kepulauan Bangka Belitung belum memainkan perannya yang lebih besar dalam penegakan hukum lingkungan. Undang-undang lingkungan hidup tidak akan memenuhi target penghijauan jika tidak ada kerja sama antar stakeholder. Konsep kewarganegaraan ekologis ditentukan dalam upaya untuk memperluas hak-hak lingkungan berlandaskan hukum, budaya kearifan lokal, dan politik.

Kewarganegaraan ekologis telah disarankan sebagai penggerak perilaku cinta lingkungan dengan menerapkan hak-hak lingkungan dalam konstitusi yang merupakan bagian dari upaya mewujudkan politik berkelanjutan untuk melaksanakan tanggung jawab terhadap kelestarian lingkungan hidup. Mengembangkan aparatur penegak hukum lingkungan yang tegas dalam melakukan pengawasan dapat menjamin penetapan sanksi bagi yang terbukti melakukan kejahatan lingkungan hidup. Sanksi berupa Pencabutan Izin Usaha Penambangan (IUP) dan Hutan Tanaman Industri (HTI) yang disuarakan WALHI dan GAPABEL bertujuan untuk mengawasi kebijakan pemerintah 
agar tidak merampas hak-hak petani dan nelayan. Oleh karena itu, pemerintah harus mementingkan kepentingan masyarakat dengan mengoptimalkan manfaat sumber daya.

\section{Kampanye Media Sosial}

Peranan media sosial diharapkan dapat mendukung pembangunan yang berkelanjutan secara aktif dalam menyelesaikan masalahmasalah lingkungan hidup. Pemberitaan media tentang masalah lingkungan memberikan wawasan terhadap publik dan meningkatkan kesadaran publik tentang lingkungan hidup. Publikasi mengenai lingkungan hidup dapat dilakukan melalui berbagai media online, antara lain blog, twitter, youtube, dan facebook. Pengenalan tentang masalah lingkungan tidak hanya dilakukan oleh wartawan tetapi juga dapat dilakukan oleh organisasi masyarakat, pemerintah, swasta, maupun individu pribadi (Peeples, 2015). Pemberitaan lingkungan hidup di Provinsi Kepulauan Bangka Belitung melalui media sosial yang jelas dapat menyediakan informasi dan memberikan pengetahaun kepada masyarakat. Media sosial yang dimiliki WALHI, GAPABEL dan DLH Provinsi Kepulauan Bangka Belitung meliputi blog, facebook, twiter, instagram dan youtube untuk memberikan kesadaran kepada masyarakat tentang kondisi lingkungan.

Media sosial memainkan peran penting dalam mendidik warga negara secara profesional tentang pentingnya menjaga lingkungan. Tanpa peran media, tata kelola setiap masalah lingkungan bersifat tertutup karena LSM, kelompok warga, komunitas, atau bahkan pejabat publik baru melaporkan masalah lingkungan yang sudah kritis. Saat ini banyak jaringan media baru yang membahas isu-isu lingkungan, akan tetapi dihalangi oleh tiga faktor, yaitu: (a) news media yang hanya menanggapi berita dari siaran pers resmi, pernyataan pejabat publik, dan pengumuman tentang peraturan dan undang-undang, (b) tidak ada kelompok wartawan yang secara signifikan mengedepankan isu-isu lingkungan, (c) dan masalah lingkungan hanya tercakup ketika ada krisis, bukan risiko, tetapi krisis yang sedang berlangsung dan aktif (Chavez, et al, 2018). Pemberitaan jaringan media tentang masalah lingkungan membentuk perdebatan tentang isu-isu dan kebijakan lingkungan. Media sosial berperan sebagai penyampai berita utama terutama masalah penambangan timah dan masalah sampah yang ada di Provinsi Kepulauan Bangka Belitung.

\section{SIMPULAN}

Gerakan kewarganegaraan ekologis dilakukan melalui gerakan reklamasi pasca penambangan, gerakan penanaman bakau, gerakan perlawanan izin usaha penambangan dan hutan tanaman industri, gerakan aksi peduli sampah dengan melakukan bersihbersih pantai, pengadaan tong sampah, pengolahan sampah menjadi kompos dan pembuatan kerajinan tangan. Pembentukan karakter peduli lingkungan dapat dilakukan dengan pendidikan lingkungan yang dilakukan di sekolah dan masyarakat, penegakan hukum pengelolaan lingkungan hidup, dan kampanye melalui media sosial blog, facebook, instagram, youtube dan twitter.

\section{DAFTAR RUJUKAN}

Aditjondro, G. J. (2003). Pola-Pola Gerakan Lingkungan: Refleksi Untuk Menyelamatkan Lingkungan Dari Ekspansi Modal. Yogyakarta: Pustaka Pelajar.

Anantharaman, M. (2014). Networked Ecological Citizenship, The New Middle Classes and The Provisioning of Sustainable Waste Management in Bangalore, India. Journal of Cleaner Production, 63, 173-183.

Antwi, et. Al,. (2014). Land cover transformation in two post-mining landscapes subjected to different 
ages of reclamation since dumping of spoils. SpringerPlus, 3, 702, 1-22.

Asshiddiqie, J. (2009). Green Constitution Nuansa Hijau Undang-Undang Dasar Negara Republik Indonisia tahun 1945. Jakarta: Rajawali Pers.

Awaliyah, S., Al Atok, R., \& Wulandari, N. A. T. (2018). The Implementation of Regulation of the Minister of Education and Culture Number 23 Year 2015 Concerning Character Development in the Middle School. 251(23), 367-370. https://doi.org/10.2991/acec-18.2018.84

Bozek, J. (2011). “Tree Day" educational programme. dalam, The Civic Inspirer A Guide To Informal Civic Education At (And Not Only) Public Librarie. The Foundation Institute of Public Affairs. Poland.

BPS. (2018). Statistik Daerah Provinsi Kepulauan Bangka Belitung 2018. BPS Provinsi Kepulauan Bangka Belitung.

Chavez, M. (2018). The News Media and Environmental Challenges in Mexico: The Structural Deficits in The Coverage and Reporting by The Press. Chapter 2. 19-44.

Creswell, J.W. (2015). Research Design: Pendekatan Kualitatif, Kuantitatif, dan Mixed. Yogyakarta: Pustaka Pelajar. Edisi ketiga.

DLH. (2017). Renstra Strategis Dinas Lingkungan Hidup 2017 - 2022 Provinsi Kepulauan Bangka Belitung Ghosh, S. (2015). Learning From Community: Agenda For Citizenship Education. Education, Citizenship and Social Justice. 10 (1), 21-36.

Gunanti, D. (2012). Meranap Pembelajaran Pendidikan Lingkungan Hidup dalam Konfigurasi Pendidikan Kewarganegaraan. PKn progresif, 7 (2). 140-151.

Humphreys, D. (2009). Environmental and Ecological Citizenship in Civil Society. The international spectator,
44 (1), 171-183.

Irawan, R.R. (2014). Stakeholder Management: Conflict and Interest in Tin Mining Industry Indonesia (Case study Bangka Belitung province). European Scientific Journal. 10 (25). 75-89.

Jagers., et al. (2014). Ecological Citizenship: A Driver of Pro-Environmental Behaviour?. Environmental Politics, 23 (3), 434-453.

Kalidjernih, F. K, (2011). Puspa Ragam Konsep dan Isu Kewarganegaraan. Bandung: Widya Aksara Press. Edisi ketiga.

Kennedy, E. H. (2011). Rethinking Ecological Citizenship: The Role of Neighbourhood Networks In Cultural Change. Environmental Politics, 20 (6), 843-860.

Keraf, A.S. (2014). Filsafat Lingkungan Hidup: Alam Sebagai Sebuah Sistem Kehidupan Bersama Fritjof Capta. Yogyakarta: Penerbit PT Kanisius.

Keulartz, J. (2018). Does Deliberation Promote Ecological Citizenship?

The Convergence Hypothesis and the Reality of Polarization. Dalam. S. Sarkar and B. A. Minteer (eds.). A Sustainable Philosophy The Work of Bryan Norton, The International Library of Environmental, Agricultural and Food Ethics.

Laporan Tahunan PT Timah Tbk. (2017). Togetherness for better future.

Latchem, C. (2018). Open and distance non-formal education in developing countries. Springer: Singapore.

Latta, X., \& Wittman, H. (2014). Ecological Citizenship in Latin America. dalam E. Isin and P. Nyers (eds), The Routledge Handbook of Global Citizenship Studies. London: Routledge, 265-273.

Murdiantum \& Daryanto. (2015). Pengelolaan kesehatan lingkungan. Yogyakarta: Penerbit Gava Media.

Nomura, K. (2009). Democratization and the politics of environmental claim- 
making. South East Asia Research, 17 (2), 261-285.

Nurmayanti, I., \& Harmanto. (2017). Strategi yayasan mangrove center tuban dalam mengembangkan ecological citizenship pada masyarakat tuban. Jurnal kajian moral dan kewarganegaraan, 5 (2), 83-97.

Peeples, J. (2015). Discourse/Rhetorical Analysis Approaches to Environment, Media, And Communication". dalam. Anders Hansen \& Robert Cox. The routledge handbook of environment and communication. London and New York: Routledge.

Prasetiyo, W.H. \& Budimansyah, D. (2016). Warga Negara dan Ekologi: Studi Kasus Pengembangan Warga Negara Peduli Lingkungan dalam Komunitas Bandung Berkebun. Jurnal pendidikan humaniora, 4 (4), 177-186.

Renthlei, L. (2016). Governance and Environmental Protection in Mizoram. Indian Journal of Public Administration, 62 (3), 645-656.

Report UNDP-UNEP. (2015). Climate Public Expenditure Andinstitutional Review Of Bangkabelitung Island Of Indonesia. Center for Climate Finance and Multilateral PolicyFiscal Policy AgencyMinistry of Finance, Republic of Indonesia

Samsuri. (2011).Pendidikan Kewarganegaraan Sebagai Wahana Membangun Karakter Warga Negara Demokratis. dalam Pendidikan karakter dalam perspektif teori dan praktek, 356-383. Yogyakarta: UNY Press.
Shin, S. (2015). Environmental Policy in East Asia Institutions in Comparative Perspective. Dalam. Routledge Handbook of Environment and Society in Asia. London and New York: Routledge.

Singh, P.K. et al. (2017). A New Model of Exact Reclamation of Post-mining Land to Address Land Acquisition Problem in Indian Coal Mining Industry. Journal Geological Society Of India, 89, 307-314.

Smith, M.J. \& Pangsapa, P. (2008). Environment and Citizenship Integrating Justice, Responsibility and Civic Engagement. London: Zed Books.

Syahri, M. (2013). Bentuk-Bentuk Partisipasi Warga Negara dalam Pelestarian Lingkungan Hidup Berdasarkan Konsep Green Moral di Kabupaten Blitar. Jurnal Penelitian Pendidikan, 13 (2), 119-134.

The Danish Egyptian Dialogue Institute. (2016). The Road to Citizenship Education in Egypt.

Toumbourou, T. (2011). Asia-Pacific. Alternative Law Journal, 36 (1), 54-55.

UNEP \& CAEC. (2014). Enforcement of Environmental Law: Good Practices from Africa, Central Asia, ASEAN Countries and china. Beijing. China.

Vasi, I.B. (2011). WINDS OF CHANGE The Environmental Movement and the Global Development of the Wind Energy Industry. New York: Oxford University Press. 